\title{
Kontribusi Kepemimpinan Tranformasional Kepala Sekolah Dan Komitmen Organisasi Terhadap Kinerja Guru
}

\author{
Ni Made Suastini ${ }^{1 *}$, Ida Bagus Surya Manuaba ${ }^{2}$ iD \\ 1,2 Jurusan Pendidikan Dasar, Universitas Pendidikan Ganesha, Singaraja, Indonesia \\ *Corresponding author: nimadesuastini22@undiksha.ac.id
}

\begin{abstract}
Abstrak
Mulai menurunnya kualitas kenerja guru dipengaruhi oleh beberapa faktor, baik itu faktor internal maupun faktor eksternal seperti gaya kepemimpinan kepala sekolah dan komitmen organisasi yang dimiliki oleh seorang guru. Tujuan dari penelitian ini adalah untuk mengetahui besaran kontribusi kepemimpinan transformasional kepala kekolah dan komitmen organisasi terhadap kinerja guru di Sekolah Dasar. Penelitian ini merupakan penelitian ex post facto. Dengan jumlah populasi penelitian 32 orang guru sekolah dasar. Teknik pengembilan sampel pada penelitian ini dilakukan dengan menggunakan teknik sampling total yakni menggunakan seluruh populasi sebagai sampel penelitian. Pengumpulan data dalam penelitian ini dilakukan memberikan angket/kuisioner kepada sampel serta melakukan pencatatan dokumen. Analisis data dilakukan dengan menggunakan teknik regresi sederhana dan teknik regresi ganda. Hasil penelitian ini menunjukkan bahwa terdapat kontribusi yang signifikan kepemimpinan transformasional kepala sekolah terhadap kinerja guru dibuktikan berdasarkan nilai $\mathrm{r}_{\text {hitung }}=0,723>\mathrm{r}_{\text {tabel }}=0,361$ dan kontribusi sebesar 52\%, terdapat kontribusi yang signifikan komitmen organisasi terhadap kinerja guru dibuktikan berdasarkan nilai $\mathrm{r}_{\text {hitung }}=0,735>\mathrm{r}_{\text {tabel }}=0,361$ dan kontribusi sebesar $54 \%$, terdapat kontribusi yang sigmifikan kepemimpinan transformasional kepala sekolah dan komitmen organisasi terhadap kinerja guru dibuktikan berdasarkan nilai $r_{\text {hitung }}=31,207>\mathrm{r}_{\text {tabel }}=0,361$ dan kontribusi sebesar $68 \%$. Sehingga dapat disimpulkan bahwa secara bersama-sama kepemimpinan transformasional kepala sekolah dan komitmen organisasi berpengaruh terhadap kinerja guru.
\end{abstract}

Kata kunci: Kepemimpinan Transformasional, Komitmen Organisasi, Kinerja Guru

\section{Abstract}

It is necessary to optimize the contribution of the principal's transformational leadership and organizational commitment to teacher performance.This study intends to determine (1) To determine the amount of the principal's transformational leadership contribution to the teacher's performance at SD Gugus V Abiansemal, To determine the amount of contribution of organizational commitment to teacher performance at SD Gugus V Abiansemal, (3) To determine the amount of contribution headmaster transformational leadership and organizational commitment to teacher performance at SD Gugus $V$ Abiansemal. This research is an ex post facto research. The population in this study were as straight as civil servant teachers in SD Gugus V Abiansemal, totaling 32 people. The sampling technique used in this study was total sampling. The sample in this study consisted of 32 people. The data collection method used in this study is the civil servant teacher at SD Gugus $V$ Abiansemal. The conclusions of this study are (1) there is a significant contribution of principal transformational leadership to teacher performance as evidenced by the value of rcount $=0.723>$ rtabel $=0.361$ and a contribution of 52\%, (2) there is a significant contribution of organizational commitment to teacher performance as evidenced by value rhitung $=$ $0.735>$ rtabel $=0.361$ and a contribution of 54\%, (3) there is a significant contribution of the principal's transformational leadership and organizational commitment to teacher performance as evidenced by the value of rhitung $=31.207>$ rtabel $=$ 0.361 and a contribution of $68 \%$.

Keywords: Principal Transformational Leadership, Organizational Commitment, Teacher Performance
History:
Received : 20 Januari 2021
Revised : 28 JAnuari 2021
Accepted : 6 Februari 2021
Published : 25 Maret 2021

Publisher: Undiksha Press

Licensed: This work is licensed under

a Creative Commons Attribution 4.0 License

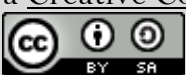




\section{Pendahuluan}

Pendidikan merupakan suatu kebiasaan yang dilakukan oleh sekelompok individu untuk dapat meningkatkan mutu dan kualitas sumber dayanya agar mampu bersaing pada era globalisasi seperti saat ini (Ideswal, 2019; Muliandari, 2019). Pendidikan menjadi salah satu aspek penting dalam mengembangkan potensi anak serta mampu memberikan peluang bagi anak untuk bersaing dalam bidang akademik maupun non akademik (Lusiana, 2019). Untuk memperoleh suatu pendidikan yang berkualitas maka faktor penting yang harus dipenuhi adalah keberadaan guru, kepala sekolah yang bermutu, yang professional, sejahtera dan bermartabat (Prasetyono, 2020). Guru serta kepala sekolah merupakan titik yang strategis dalam kegiatan pendidikan sehingga memiliki pengaruh yang signifikan terhadap kemajuan kualitas pendidikan (Indrawan, 2018; Oupen, 2020). Guru juga memegang peranan dalam membentuk karakter bangsa serta mengembangkan potensi siswa dalam menentukan keberhasilan pendidikan serta peserta didik terutama dalam kaitannya dengan proses belajar mengajar (Nurfasicha, 2020; Salihin, 2019). Profesionalisme guru sebagai ujung tombak di dalam implementasi kurikulum di kelas yang perlu mendapat perhatian (Suarya, 2018). Hal ini dikarenakan profesionalitas guru akan berpengaruh terhadap kualitas pendidikan sehingga peningkatan kenerja guru menjadi salah satu upaya untuk meningkatkan kualitas pendidikan (Adzkiya, 2020; Benardi, 2018).

Kinerja guru diartikan sebagai kemampuan seorang guru dalam melaksanakan tugas pembelajaran dan bertanggung jawab atas peserta didik di bawah bimbingannya dengan meningkatkan prestasi belajar peserta didik (Salihin, 2019). Kinerja guru juga diartikan sebagai usaha tinggi yang dilakukan oleh guru dalam melaksanakan tugas-tugasnya sebagai guru, dalam upaya mencapai tujuan pembelajaran (Wasito, 2021). Dalam hal ini guru yang melaksanakan pekerjaan pada lembaga pendidikan wajib memiliki kualifikasi tersebut yang menjamin keahlian, kemahiran atau kecakapannya sebagai pendidik profesional (Wahidin, 2020). Profesionalitas guru yang memenuhi standar tersebut merupakan pendukung terciptanya kualitas seorang guru dalam menjalankan pekerjaannya.

Namun pada kenyataannya penelitian yang dilakukan oleh Hartanti \& Yuniarsih (2018) menemukan bahwa dalam beberapa tahun terakhir terjadi penurunan terhadap kinerja guru, hal ini dapat dilihat dari tingginya jumlah ketidakhadiran guru untuk mengajar dan rendahnya nilai kinerja guru. Hal ini juga didukung oleh hasil penelitian Prabu \& Puspitasari (2015) yang juga menunjukkan bahwa guru terkadang merasa setres dalam melaksanakan proses pembelajaran, setres yag dialami oleh guru ditandai dengan munculnya gejala tidak sabaran dalam menghadapi siswa di kelas, lekas marah, bersikap apatis, sering tidak masuk kerja (rata-rata kehadiran kurang dari 90\%) dan sebagainya yang pada akhirnya dapat berdampak pada kinerja guru. Penurunan kinerja guru disebabkan oleh beberapa faktor baik itu faktor internal maupun eskternal, seperti setres, motivasi kerja, komitmen, lingkungan kerja, kepemimpinan kepala sekolah, dll (Priyono et al., 2018).

Kepemimpinan kepala sekolah merupakan salah satu faktor penentu kualitas kinerja guru, hal ini dikarenakan dalam lingkungan sekolah kepala sekolah berperan sebagai penggerak sehingga harus mampu menjadi panutan bagi guru, tenaga administrasi dan juga semua warga sekolah lainnya serta mampu menstimulir, mendorong, dan atau membimbing guru-guru menuju perkembangan yang berkesinambungan sehingga mereka mampu menjalankan tugas atau kinerjanya dengan optimal (Akbar, 2019; Aninda, 2018; Priyono et al., 2018). Sehingga kualitas kepemimpinan kepala sekolah sangat diperlukan bagi keberhasilan pelaksanaan kegiatan di sekolah (Juniarti, 2019). Untuk meningkatkan komitmen kerja guru, maka kepala sekolah perlu memperhatikan cara kepemimpinannya (Imansyah, 2020). Selain itu, kinerja kepemimpinan kepala sekolah adalah prestasi atau sumbangan yang diberikan oleh kepemimpinan seorang kepala sekolah, baik secara kuantitatif maupun kualitatif yang terukur dalam rangka membantu tercapainya tujuan 
sekolah (Sitompul, 2019). Gaya kepemimpinan mempunyai pengaruh yang positif bagi kinerja guru (Fairy, 2019). Kualitas kepemimpinan kepala sekolah tanpa didukung oleh kinerja guru maka pendidikan sebagai organisasi sekolah tidak akan berhasil (Handayani, 2020). Salah satunya yaitu kepemimpinan transformasional.

Kepemimpinan transformasional merupakan kemampuan seseorang pemimpin bekerja dengan dan atau melalui orang lain untuk mentransformasikan secara optimal sumber daya dalam rangka mencapai tujuan yang bermakna sesuai dengan target capaian yang telah ditetapkan (B.K, 2019). Kepemimpinan transformasional kepala sekolah akan memberi rasa aman, percaya diri, dan saling percaya bagi guru untuk mengembangkan segi profesionalnya (Azizah, 2019). Selain itu juga memberikan pengaruh yang sangat positif terhadap organisasi yang akan memberikan motivasi serta kepercayaan lebih bagi guru (Purwanto, 2020). Dengan menerapkan kepemimpinan transformasional kepala sekolah akan mampu mengarahkan kinerja guru yang profesional (Rifa'i, 2020).

Selain dipengaruhi oleh kepemimpinan kepala sekolah kualitas kinerja guru juga disebabkan oleh komitmen dan profesionalisme guru saat mengajar sebagai inti dari proses pendidikan (Prasetya, 2020). Komitmen memiliki peran penting terutama pada kinerja seseorang ketika bekerja, hal ini disebabkan oleh adanya komitmen yang menjadi acuan serta dorongan yang membuat mereka lebih bertanggung jawab terhadap kewajibannya (Trisnowati, 2019). Komitmen organisasi merupakan derajat yang mana karyawan percaya dan menerima tujuan-tujuan organisasi yang akan tetap tinggal atau tidak akan meninggalkan organisasi (Hayati, 2020). Komitmen organisasi menuntut guru melaksanakan pekerjaan sesuai dengan jadwal, kurikulum, kebijakan-kebijakan, demikian juga interaksi sosial yang terjadi dengan struktur-struktur tersebut (Gumilar, 2020). Sesuai dengan kinerja guru maka yang menjadi komitmen organisasi bersama merupakan menjalankan tugas sesuai standar pencapaian tugas guru berdasarkan kompetensi yang harus dimiliki oleh guru dalam hal mendidik, mengajar, membimbing dan melatih (Hersanti, 2020).

Penelitian yang dilakukan oleh Wardoyo (2018) menunjukkan bahwa terdapat kontribusi positif antara kepemimpinan transformasional, iklim organisasi sekolah dan dan motivasi berprestasi terhadap kinerja guru sebesar 59,7\%. Hal ini juga didukung oleh hasil penelitian Tanjung (2019) yang juga menunjukkan bahwa persepsi tentang kepemimpinan transformasional kepala sekolah berpengaruh positif terhadap motivasi berprestasi guru SMP Negeri di Wilayah Tanjung Morawa. Serta penelitian yang dilakuka oleh Zulkarnaen (2020) yang menunjukkan bahwa terdapat pengaruh positif antara gaya kepemimpinan transformasional terhadap kinerja guru SMK, atinya penerapan gaya kepemimpinan transformasional secara terpat dapat meningkatkan kinerja guru SMK Berdasarkan pemaparan di atas kepemimpinan transformasional kepala sekolah dan komitmen organisasi sangat mempengaruhi kemajuan sekolah dan peningkatan kinerja guru.

Maka berdasarkan penelitian relevan tersebut dilakukan penelitian dengan judul "Kontribusi Kepemimpinan Transformasional Kepala Sekolah dan Komitmen Organisasi Terhadap Kinerja Guru di SD Gugus V Abiansmal Tahun Ajaran 2020/2021". Penelitian ini berfokus pada kontribusi kepemimpinan transformasional kepala sekolah dan komitmen organisasi terhadap kinerja guru yang dilaksanakan di SD Gugus V Abiansemal dengan tujuan untuk untuk mengetahui besaran kontribusi kepemimpinan transformasional kepala kekolah dan komitmen organisasi terhadap kinerja guru di SD Gugus V Abiansemal. Penelitian ini berfokus untuk mengetahui kontribusi kepemimpinan tranformasional kepala sekolah dan komitmen organisasi terhadap kinerja guru.

\section{Metode}

Penelitian ini dilaksanakan pada guru di SD Gugus V Abiansemal. Penelitian ini dilakukan dengan menggunakan rancangan ex post facto dengan jenis studi penelitian 
korelasi. Variabel dalam penelitian ini terdiri dari kepemimpinan kepala sekolah $\left(\mathrm{X}_{1}\right)$ sebagai variabel bebas, komitmen organisasi $\left(\mathrm{X}_{2}\right)$ sebagai variabel bebas dan kinerja guru (Y) sebagai variabel terikat. Adapun gambar variabel penelitian ini sebagai berikut.

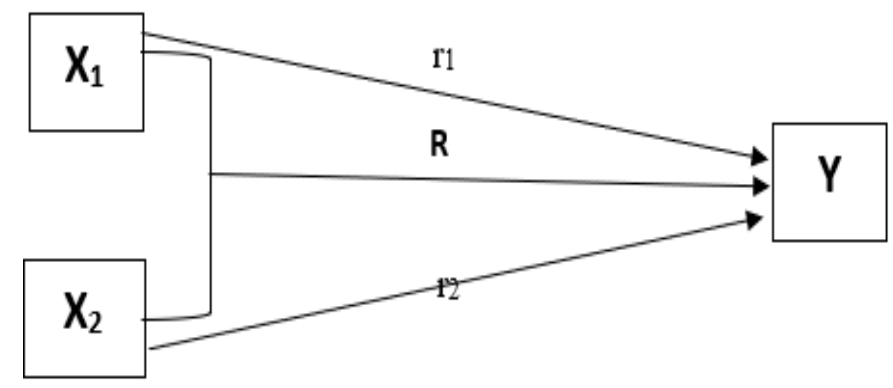

Gambar 1. Pradigma Ganda dengan Dua Variabel Independen

Populasi dalam penelitian ini adalah SD Gugus V Abiansemal dengan total sampel sebanyak 32 orang guru yang terdiri dari: SD No. 1 Abiansemal sebanyak 6 orang, SD No. 2 Abiansemal sebanyak 5 orang, SD No. 3 Abiansemal sebanyak 6 orang, SD No. 4 Abiansemal sebanyak 3 orang, SD No. 5 Abiansemal sebanyak 6 orang dan SD No. 6 Abiansemal sebanyak 6 orang. Teknik yang digunakan dalam mengambil sampel adalah teknik nonprobability sampling yaitu teknik sampling total. Pengumpulan data dalam penelitian ini dilakukan dengan menggunakan metode non tes berupa angket/kuisioner dan pencatatan dokumen. Teknik analisis yang digunakan dalam penelitiani ini adalah teknik regresi sederhana dan teknik regresi ganda.

\section{Hasil dan Pembahasan \\ Hasil}

Data mengenai kinerja guru di SD Gugus V Abiansemal diperoleh melalui pencatatan dokumen, dokumen tersebut adalah penilaian kinerja guru (PKG) dengan meminta ijin kepada kepala sekolah di Guggus V Abiansemal. Pencatatan dokumen sesuai dengan jumlah responden yaitu 32 responden. Adapun hasil deskrispsi data penilaian kinerja guru sebagai berikut.

Tabel 1. Deskripsi Data Kinerja Guru di Gugus V Abiansemal

\begin{tabular}{lc}
\hline \multicolumn{1}{c}{ Analisis Statistik } & Kinerja Guru \\
\hline Sampel & 32 \\
Skor Maksimum & 96.43 \\
Skor Minimum & 82,14 \\
Mean & 87,723 \\
Standar Deviasi & 2.8959 \\
\hline
\end{tabular}
Patokan).

Selanjutnya data penelitian dikatagorikan kedalam skala PAP (Penilaian Acuan

Tabel 2. Konvernsi PAP Skala Lima Kinerja Guru di Gugus V Abiansemal

\begin{tabular}{ccc}
\hline Presentase Penguasaan & Kategori & Persentase Kinerja Guru \\
\hline $90-100$ & Sangat tinggi & $10,52 \%$ \\
$80-89$ & Tinggi & $8,55 \%$ \\
$65-79$ & Sedang & $25,65 \%$
\end{tabular}




\begin{tabular}{ccc}
\hline Presentase Penguasaan & Kategori & Persentase Kinerja Guru \\
\hline $55-64$ & Rendah & $16,44 \%$ \\
$0-54$ & Sangat Rendah & 38,81 \\
\hline
\end{tabular}

Berdasarkan Tabel 2 tersebut, menunjukan bahwa rata-rata nilai kinerja guru yang diperoleh adalah 87,723 berada pada rentang 90-100 dengan kategori sedang, dengan jumlah presentase siswa dalam kategori tersebut yaitu 10,52\%. Data tentang kepemimpinan Transformasional kepala sekolah di SD Gugus V Abiansemal diperoleh melalui penyebaran angket kepemimpinan transformasional kepala sekolah. Adapun hasil deskripsi data kepemimpinan transformasional kepala sekolah yang dinyatakan valid dapat dilihat pada Tabel 3 sebagai berikut.

Tabel 3. Deskripsi Data Kepemimpinan Transformasional Kepala Sekolah di Gugus V Abiansemal

\begin{tabular}{lc}
\hline \multicolumn{1}{c}{ Analisis Statistik } & Kepemimpinan Transformasional Kepala Sekolah \\
\hline Sampel & 32 \\
Skor Maksimum & 128 \\
Skor Minimum & 94 \\
Mean & 109,218 \\
Standar Deviasi & 9,931 \\
\hline
\end{tabular}

Berdasarkan data tersebut, maka deskripsi data budaya sekolah dapat menentukan katagori dalam skala lima teoretik skor kepemimpinan transformasional kepala sekolah. Skala lima teoretik yang digunakan untuk mengetahui hasil budaya sekolah di SD V Abiansemal.

Tabel 4. Kategori Skor Skala Lima Teoretik Kepemimpinan Transformasional Kepala Sekolah di SD Gugus V Abiansemal

\begin{tabular}{ccc}
\hline Rentang & Hasil & Kategori \\
\hline $\mathrm{M}_{\mathrm{i}}+1,5 \mathrm{SD}_{\mathrm{i}} \rightarrow \mathrm{M}_{\mathrm{i}}+3,0 \mathrm{Sd}_{\mathrm{i}}$ & $104-128$ & Sangat baik \\
$\mathrm{M}_{\mathrm{i}}+0,5 \mathrm{SD}_{\mathrm{i}} \rightarrow \mathrm{M}_{\mathrm{i}}+1,5 \mathrm{Sd}_{\mathrm{i}}$ & $88-104$ & Baik \\
$\mathrm{M}_{\mathrm{i}}-0,5 \mathrm{SD}_{\mathrm{i}} \rightarrow \mathrm{M}_{\mathrm{i}}+0,5 \mathrm{Sd}_{\mathrm{i}}$ & $72-88$ & Cukup \\
$\mathrm{M}_{\mathrm{i}}-1,5 \mathrm{SD}_{\mathrm{i}} \rightarrow \mathrm{M}_{\mathrm{i}}-0,5 \mathrm{Sd}_{\mathrm{i}}$ & $56-72$ & Tidak Baik \\
$\mathrm{M}_{\mathrm{i}}-3,0 \mathrm{SD}_{\mathrm{i}} \rightarrow \mathrm{M}_{\mathrm{i}}-1,5 \mathrm{Sd}_{\mathrm{i}}$ & $32-56$ & Sangat Tidak Baik \\
\hline
\end{tabular}

Berdasarkan Tabel 4 tersebut, menunjukan rerata (mean) dari kepemimpinan transformasional kepala sekolah adalah 109,218 dan nilai tersebut berada pada rentang 109 128. Maka dapat disimpulkan bahwa data kepemimpinan transformasional kepala sekolah di SD Gugus V Abiasemal termasuk kategori sangat baik. Data tentang komitmen organisasi di SD Gugus V Abiansemal diperoleh melalui angket komitmen organisasi. Adapun hasil deskripsi data komitmen organisasi yang dinyatakan valid dapat dilihat pada Tabel 5 sebagai berikut.

Tabel 5. Deskripsi Data Komitmen Organisasi di Gugus V Abiansemal

\section{Analisis Statistik}

Sampel

Skor Maksimum

Skor Minimum

Mean

Standar Deviasi

\section{Komitmen Organisasi}

32

138

101

119,062

11,302 
Berdasarkan data tersebut, maka deskripsi data komitmen organisasi dapat menentukan kategori dalam skala lima teoretik skor komitmen organisasi. Skala lima teoretik yang digunakan untuk mengetahui hasil komitmen organisasi di SD Gugus V Abiansemal.

Tabel 6. Kategori Skala Lima Teoretik Komitmen Organisasi di SD Gugus V Abiansemal

\begin{tabular}{ccc}
\hline Rentang & Hasil & Kategori \\
\hline $\mathrm{M}_{\mathrm{i}}+1,5 \mathrm{SD}_{\mathrm{i}} \rightarrow \mathrm{M}_{\mathrm{i}}+3,0 \mathrm{Sd}_{\mathrm{i}}$ & $117-144$ & Sangat baik \\
$\mathrm{M}_{\mathrm{i}}+0,5 \mathrm{SD}_{\mathrm{i}} \rightarrow \mathrm{M}_{\mathrm{i}}+1,5 \mathrm{Sd}_{\mathrm{i}}$ & $99-117$ & Baik \\
$\mathrm{M}_{\mathrm{i}}-0,5 \mathrm{SD}_{\mathrm{i}} \rightarrow \mathrm{M}_{\mathrm{i}}+0,5 \mathrm{Sd}_{\mathrm{i}}$ & $81-99$ & Cukup \\
$\mathrm{M}_{\mathrm{i}}-1,5 \mathrm{SD}_{\mathrm{i}} \rightarrow \mathrm{M}_{\mathrm{i}}-0,5 \mathrm{Sd}_{\mathrm{i}}$ & $63-81$ & Tidak Baik \\
$\mathrm{M}_{\mathrm{i}}-3,0 \mathrm{SD}_{\mathrm{i}} \rightarrow \mathrm{M}_{\mathrm{i}}-1,5 \mathrm{Sd}_{\mathrm{i}}$ & $36-63$ & Sangat Tidak Baik \\
\hline
\end{tabular}

Berdasarkan Tabel 6 tersebut, menunjukan rerata (mean) dari komitmen organisasi adalah 119,062 dan nilai tersebut berada pada rentang 117 - 144. Maka dapat disimpulkan bahawa data komitmen organisasi di SD Gugus V Abiansemal termasuk kategori sangat baik. Pengujian hipotesis pertama dengan analisis regresi sederhana diperoleh persamaan regresi $\hat{Y}$ $=64,68+0,21 \mathrm{X} 1$ signifikan dan linier. Persamaan regresi yang telah didapat berarti bahwa setiap kenaikan 1 kali satuan kepemimpinan transformasional kepala sekolah menyebabkan kenaikan 0,21 nilai kinerja guru pada konstanta 64,68, sehingga H0 yang menyatakan tidak terdapat pengaruh yang signifikan kepemimpinan transformasional kepala sekolah terhadap kinerja guru di SD Gugus V Abiansemal ditolak dan Ha diterima. Hasil analisis data diperoleh koefisien determinasi R2 $=0,523$ dan kontribusinya sebesar 52\%. Hal ini berarti terdapat pengaruh yang signifikan kepemimpinan transformasioal kepala sekolah terhadap kinerja guru di SD Gugus V Abiansemal dan kontribusinya sebesar 52\%. Hasil penelitian ini sesuai dengan hasil penelitian yang dilakukan oleh Sukarini (2017). Hasil yang diperoleh yaitu terdapat kontribusi yang signifikan dari kepemimpinan transformasional terhadap kinerja guru di Universal School Denpasar dengan sumbangan efektif sebesar 20,56\%.

Pengujian hipotesis kedua dengan analisis regresi sederhana diperoleh persamaan regresi $\widehat{Y}=64,70+0,19 \mathrm{X} 2$ signifikan dan linier. Persamaan regresi yang telah didapat berarti bahwa setiap kenaikan 1 kali satuan komitmen organisasi menyebabkan kenaikan 0,19 nilai kinerja guru pada konstanta 64,70, sehingga H0 yang menyatakan tidak terdapat pengaruh yang signifikan komitmen organisasi terhadap kinerja guru di SD Gugus V Abiansemal ditolak dan Ha diterima. Hasil analisis data diperoleh koefisien determinasi R2 = 0,540 dan kontribusinya sebesar $54 \%$. Hal ini berarti terdapat pengaruh yang signifikan komitmen organisasi terhadap kinerja guru di SD Gugus V Abiansemal dan kontribusinya sebesar 54\%. Hasil penelitian ini sejalan dengan hasil penelitian yang dilakukan oleh Suardani (2017) yaitu terdapat terdapat kontribusi yang signifikan komitmen organisasi terhadap kinerja guru dengan koefisien korelasi sebesar 0,553, kontribusi sebesar 30,6\% dan sumbangan efektifnya sebesar $15,26 \%$.

Pengujian hipotesis ketiga dengan analisis regresi ganda diperoleh persamaan regresi $\widehat{Y}=58,66+0,132 \mathrm{X} 1+0,123 \mathrm{X} 2$ signifikan. Persamaan regresi yang telah didapat berarti bahwa setiap kenaikan 1 kali satuan kepemimpinan transformasional kepala sekolah dan 1 komitmen organisasi menyebabkan kenaikan kepemimpinan transformasional kepala sekolah 0,132 dan komitmen organisasi 0,123 nilai kinerja guru pada konstanta 5,66, sehingga $\mathrm{H} 0$ yang menyatakan tidak terdapat pengaruh yang signifikan kepemimpinan transformasional kepala sekolah dan komitmen organisasi terhadap kinerja guru di SD Gugus B Abiansemal ditolak dan Ha diterima. Hasil analisis data diperoleh koefisien determinasi R2 = 0,683 dan kontribusinya sebesar 68\%. Maka, hal ini berarti terdapat pengaruh yang signifikan kepemimpinan transformasional kepala sekolah dan komitmen organisasi terhadap kinerja guru di SD Gugus V Abiansemal dan kontribusinya sebesar 68\%. Kontribusi kepemimpinan 
transformasional dan komitmen organisasi secara bersama-sama terhadap kinerja guru adalah sebesar 68\%. Hasil ini menunjukkan bahwa masih terdapat sekitar $32 \%$ faktor lain yang memengaruhi kinerja guru di SD Gugus V Abiansemal baik faktor internal maupun faktor eksternal.

\section{Pembahasan}

Temuan pertama dalam penelitian menunjukkan bahwa kepemimpinan transformasional kepala sekolah memberikan pengaruh yang signifikan terhadap kinerja guru. Hal ini ditunjukkan dengan perolehan koefisien determinasi $\mathrm{R} 2=0,523$ dan kontribusinya sebesar 52\%. Hasil yang diperoleh dalam penelitian ini sejalan dengan hasil penelitian yang dilakukan oleh Purwanto (2020) yang juga menunjukkan bahwa gaya kepemimpinan transformasional kepala sekolah berpengaruh secara positif dan signifikan terhadap kinerja guru. Hal ini menunjukkan bahwa kualitas kinerja guru bergantung pada gaya kepemimpinan kepala sekolah, apabila kepala sekolah dapat memimpin dengan baik maka kualitas kinerja guru juga akan baik, begitu juga berlaku sebaliknya (Ahmad, 2018; Fraliantina, 2016). Sehingga dapat dikatakan bahwa kunci dari kinerja seorang guru adalah gaya kepemimpinan kepala sekolah (Priyono et al., 2018). Dalam menjalankan fungsinya sebagai administarator, educator, manajer, supervisor, motivator, leader,inovator serta sebagai sorang enterpreneur kepala sekolah dituntut untuk memimpin secara profesional dan bertanggung jawab, sehingga dengan kemampuan tersebut akan lebih mendorogterlaksananya penyelenggaraan pendidikan di sekolah dengan baik serta tercapainya tujuan pendidikan nasional (Ahmad, 2018; Akbar, 2019).

Temuan kedua, dalam penelitian ini menunjukkan bahwa terdapat pengaruh yang signifikan komitmen organisasi terhadap kinerja guru di SD Gugus V Abiansemal. Hal ini ditunjukkan dengan hasil analisis data diperoleh nilai koefisien determinasi $\mathrm{R} 2=0,540$ dan kontribusinya sebesar 54\%. Hasil dalam penelitian ini sejalan dengan hasil penelitian (Prasetyono, 2020) yang juga menunjukkan bahwa terdapat pengaruh yang positif antara komitmen organisasi dengan kinerja guru. Hal ini menunjukkan bahwa komitmen oragnisasi guru yang tinggi akan dapat memberikan pengaruh yang baik terhadap kualitas kinerja guru, begitu pula berlaku sebaliknya (Adzkiya, 2020). Komitmen guru merupakan salah satu bentuk prilaku guru dalam melaksanakan proses belajar mengajar di sekolah, sehingga secara tidak langsung komitmen guru akan mempengaruhi kualitas pembelajaran (Purwoko, 2018).

Temuan ketiga, dalam penelitian ini menunjukkan bahwa terdapat pengaruh yang signifikan kepemimpinan transformasional kepala sekolah dan komitmen organisasi terhadap kinerja guru di SD Gugus V Abiansemal. Hal ini dapat diketahui melalui hasil analisis data yang memperoleh koefisien determinasi $\mathrm{R} 2=0,683$ dan kontribusinya sebesar $68 \%$, yang berarti bahwa secara bersama-sama kepemimpinan transformasional kepala sekolah dan komitmen organisasi berpengaruh terhadap kualitas kinerja guru. Kepemimpinan tranformasional kepala sekolah merupakan salah satu faktor eskternal yang akan mempengaruhi kualitas kinerja guru. Hal ini dikarenakan Kepemimpinan transformasional kepala sekolah akan dapat memberi rasa aman, percaya diri, dan saling percaya bagi guru untuk mengembangkan segi profesionalnya (Azizah, 2019). Sedangkan komitmen merupakan salah satu faktor internal yang akan mempengaruhi kinerja guru. Selain komitmen terdapat faktor-faktor lain yang akan mempengaruhi kenerja guru seperti motivasi, kondisi fisik, setres, dan beberapa faktor lainnya (Purwoko, 2018). Komitmen dikatakan dapat mempengaruhi kinerja guru dikarenkan komitmen merupakan salah satu bentu prilaku yang ditunjukkan oleh guru dalam melaksanakan proses pembelajaran. Dengan adanya komitmen oragnisasi guru akan memiliki acuan serta dorongan yang dapat membuat mereka lebih bertanggung jawab terhadap kewajibannya (Trisnowati, 2019). Komitmen organisasi akan menuntut guru untuk melaksanakan pekerjaan sesuai dengan jadwal, kurikulum, 
kebijakan-kebijakan, demikian juga interaksi sosial yang terjadi dengan struktur-struktur tersebut (Gumilar, 2020).

\section{Simpulan}

Berdasarkan hasil analisis data yang telah dilaksanakan maka dapat disimpulkan bahwa.Terdapat pengaruh yang signifikan antara kepemimpinan transformasional kepala sekolah terhadap kinerja guru di SD Gugus V Abiansemal. Terdapat pengaruh yang signifikan antara komitmen organisasi terhadap kinerja guru di SD Gugus V Abiansemal. Secara besama-sama terdapat pengaruh yang signifikan antara kepemimpinan transformasional kepala sekolah dan komitmen organisasi terhadap kinerja guru di SD Gugus V Abiansemal. Perlu adanya pengoptimalan kontribusi kepemimpinan transformasional kepala sekolah dan komitmen organisasi terhadap kinerja guru. Sebagai tindak lanjut dari hasil penelitian, maka penelitian ini disarankan bagi guru, harus selalu memperbaiki kinerja sebagai seorang pendidik yang professional sesuai dengan perkembangan ilmu pengetahuan dan teknologi dan globalisasi. Bagi kepala sekolah, harus selalu meningkatkan kemampuan manajerial sebagai kepala sekolah, mampu menunjukan kepemimpinan transformasional yang profesioanal, dan mampu menciptakan komitmen organisasi dan kinerja guru yang baik sehingga mampu membawa sekolah yang dipimpinnya menuju sekolah yang berkualitas. Bagi peneliti lainnya, temuan hasil penelitian ini dikembangkan atau dipakai sebagai bahan perbandingan apabila melakukan penelitian yang sejenis.

\section{Daftar Rujukan}

Adzkiya, A. (2020). Sekolah dan Komitmen Profesional Guru Terhadap Kinerja Guru ( Studi Kasus Di Mts Ma’ Arif Nu Kabupaten Banyumas ). Jurnal Ekonomi, Bisnis Dan Akuntansi, 22. http://jp.feb. unsoed.ac.id/index.php/jeba/article/view/1772.

Ahmad, B. (2018). Pengaruh Kepemimpinan Kepala Sekolah Terhadap Kinerja Guru Di SMP Negeri 10 Kendari. Jurnal Penelitian Pendidikan Geografi, 3(1), 90-97. https://doi.org/10.36709/jppg.v3i1.9133.

Akbar, L. (2019). Gaya Kepemimpinan Transformasional Kepala Sekolah Terhadap Kinerja Guru. Jurnal Pendidikan Manajemen Perkantoran, 4(2), 176. https://doi.org/10.17509/jpm.v4i2.18012.

Aninda, C. (2018). Pengaruh Kepemimpinan Kepala Sekolah ( School Leadership ) dan Keadilan Distributif Terhadap Komitmen Organisasi : Studi Ex Post Facto Terhadap Guru SMP Negeri di Kabupaten Cirebon. Jurnal IMProvement, 5(4), 37-45. https:// doi.org/10.21009/Improvement.051.04.

Azizah, N. (2019). Pengaruh Kepemimpinan Transformasional, Motivasi Kerja Terhadap Komitmen Organisasional dan Kinerja Guru Pada SMK Abdurrahman Wahid Lamongan. Equilibrium: Jurnal Ekonomi-Manajemen-Akuntansi, 15(2), 240. https://doi.org/10.30742/equilibrium. v15i2.683.

B.K, T. M. (2019). Pengaruh Kepemimpinan Transformasional Kepala Sekolah Terhadap Kinerja Guru. Jurnal Wahana Karya Ilmiah Pendidikan, 3(2), 364-384.

Benardi, A. I. (2018). Evaluasi Kompetensi Profesionalisme Guru Mata Pelajaran Geografi dan IPS di SMP N 1 Karimunjawa, MTs dan MA NU Safinatul Huda Pulau Karimunjawa. Jurnal Ilmiah Ilmu Sosial, 4(1), 1-5. https://doi.org/10. 23887/jiis.v4i1.13905.

Fairy, N. L. N. P. O. (2019). Kontribusi Gaya Kepemimpinan Transformasional, Etos Kerja Guru, Kepuasan Kerja, dan Budaya Organisasi Sekolah Terhadap Kinerja Guru di SMPK 1 Harapan Denpasar. Jurnal Administrasi Pendidikan Indonesia, 10(2), 125131. https://doi.org/10.23887/japi. v10i2.2799.

Fraliantina, I. A. (2016). Pengaruh Kepemimpinan Dan Sarana Prasarana Olahraga Terhadap 
Prestasi Sekolah Di Bidang Olahraga. JUARA: Jurnal Olahraga, 1(2), 100. https://doi.org/10. 33222/juara.v1i2.24.

Gumilar, G. G. (2020). Organizational Commitments: Organizational Culture, School Head Leadership, School Environment, and Work Satisfaction. Jurnal Dimensi, 9(1), 4856.

Handayani, E. (2020). Kinerja Guru Ditinjau Dari Pengaruh Budaya Organisasi dan Gaya Kepemimpinan Kepala Sekolah. JMKSP (Jurnal Manajemen, Kepemimpinan, Dan Supervisi Pendidikan), 6(1). https://doi.org/10.31851 /jmksp.v6i1.3981.

Hartanti, A. S., \& Yuniarsih, T. (2018). Pengaruh Kompetensi Profesional Guru Dan Motivasi Kerja Terhadap Kinerja Guru Di Sekolah Menengah Kejuruan. Jurnal Pendidikan Manajemen Perkantoran, 3(1), 167. https://doi.org/10. 17509/jpm.v3i1.9452.

Hayati, R. (2020). Pengaruh Komitmen Organisasi dan Motivasi Kerja Terhadap Kinerja Guru. Jurnal Manajemen, Kepemimpinan Dan Supervisi Pendidikan, 5(2). http://dx.doi.org/10.31851/jmksp. v5i2.3753.

Hersanti, D. W. (2020). Analisis Pengaruh Quality Of Work Life, Motivasi Berprestasi Dan Kepemimpinan Transformasional Terhadap Kinerja Guru. Inovasi Pembelajaran Karakter (JIPK), Vol. 5, No(1), 1-7. https://i-rpp.com/index. php/jipk/article/view/1085.

Ideswal. (2019). Kontribusi Iklim Sekolah dan Kepemimpinan Kepala Sekolah terhadap Kinerja Guru Sekolah Dasar. Jurnal Basicedu, 3(2), 524-532. https://doi.org/ 10.31004/basicedu.v4i2.381.

Imansyah, M. (2020). Pengaruh Kepemimpinan Kepala Sekolah dan Partisipasi Komite Sekolah Terhadap Kinerja Guru. JMKSP (Jurnal Manajemen, Kepemimpinan, Dan Supervisi Pendidikan), 5(2), 135. https://doi.org/10.31851/jmksp.v5i2.3756.

Indrawan, K. A. (2018). Pengaruh Model Pembelajaran Somatic Auditory Visualization Intellectualy berbantuan Lingkungan Hidup terhadap Hasil Belajar IPA Siswa. Jurnal Ilmiah Sekolah Dasar, 2(1), 60. https://doi.org/10.23887/jisd. v2i1.13897.

Juniarti, E. (2019). Pengaruh Kepemimpinan Kepala Sekolah dan Efikasi Diri Guru Terhadap Kinerja Guru. Journal of Education Research, 1(2), 173-188. https://doi.org/10.47467/reslaj.v1i2.108.

Lusiana, N. P. M. (2019). Pengaruh Persepsi Guru Tentang Kepemimpinan Kepala Sekolah Terhadap Kinerja Guru di SMA Laboratorium Undiksha Singaraja Tahun Pelajaran 2017. Jurnal Pendidikan Ekonomi Undiksha, 10(2), 440. https:// doi.org/10.23887/jjpe.v10i2.20076.

Muliandari, P. T. V. (2019). Pengaruh Model Pembelajaran Kooperatif Tipe NHT (Numbered Head Together) Terhadap Hasil Belajar Matematika. International Journal of Elementary Education, 3(2), 132-140. http://dx.doi.org/10.23887/ijee. v3i2.18517.

Nurfasicha, I. (2020). Pengaruh Kepemimpinan Transformasional Kepala Sekolah, Budaya Sekolah, Dan Lingkungan Sekolah Terhadap Kinerja Guru Di Mi Islamiyah Wareng, Butuh, Purworejo, Jawa Tengah. Ibtida, Vol. 1 No(1), 67-89.

Oupen, S. M. (2020). Kontribusi Kepemimpinan Transformasional, Budaya Organisasi, Disiplin Kerja, dan Motivasi Kerja, Terhadap Komitmen Organisasional Guru SD. Jurnal Administrasi Pendidikan Indonesia, 11(1), 34-43. https://doi.org/10. 23887/japi.v11i1.3167.

Prabu, A. A. A., \& Puspitasari, M. (2015). Kecerdasan Emosi Guru, Stres Kerja, Dan Kinerja Guru Sma. Jurnal Kependidikan: Penelitian Inovasi Pembelajaran, 45(2), 113470. https://doi.org/10.21831/jk.v45i2. 7491.

Prasetya, H. Y. (2020). Supervisi Akademik Kepala Sekolah dan Komitmen Kerja Guru 
Terkait Kinerja Mengajar Guru. Jurnal Administrasi Pendidikan, 27(1), 116-124. https://doi.org/10.17509/jap.v27i1.24407.

Prasetyono, H. (2020). Pengaruh Servant Leadership, Komitmen Organisasi dan Lingkungan Fisik Terhadap Kinerja Guru. Jurnal Akuntabilitas Manajemen Pendidikan, 8(2), 108-123. https://doi.org/ 10.21831/jamp.v8i2.28458.

Priyono, B. H., Qomariah, N., \& Winahyu, P. (2018). Pengaruh Gaya Kepemimpinan, Motivasi Guru Dan Lingkungan Kerja Fisik Terhadap Kinerja Guru Sman 1 Tanggul Jember. Jurnal Manajemen Dan Bisnis Indonesia, 4(2), 144. https://doi.org/ 10.32528/jmbi.v4i2.1758.

Purwanto, A. (2020). Pengaruh Gaya Kepemimpinan Tansformational, Authentic, Authoritarian, Transactional Terhadap Kinerja Guru Madrasah Aliyah di Tangerang. Jurnal Evaluasi, 4(1), 20. https://doi.org/10.32478/evaluasi.v4i1.342.

Purwoko, S. (2018). Pengaruh kepemimpinan kepala sekolah, komitmen guru, disiplin kerja guru, dan budaya sekolah terhadap kinerja guru SMK. Jurnal Akuntabilitas Manajemen Pendidikan, 6(2), 150. https://doi.org/10.21831/amp.v6i2.8467.

Rifa'i, A. A. (2020). Pengaruh Kepemimpinan Transformasional Kepala Sekolah dan Budaya Kerja Terhadap Peningkatan Kinerja Guru. Indonesian Journal of Education Management \& Administration Review, 4. http://dx.doi.org/10.4321/ ijemar.v4i1.4379.

Salihin. (2019). Pengaruh Gaya Kepemimpinan Transformasional dan Komitmen Organisasi Terhadap Kinerja Guru Pada Sman Model Lombok Timur. Distribusi - Journal of Management and Business, 8(1), 39-52. https://doi.org/10.29303/ distribusi.v8i1.101.

Sitompul, M. K. (2019). Pengaruh Gaya Kepemimpinan Transformasional Kepala Sekolah Terhadap Komitmen Organisasi Guru Pada Sekolah Lanjutan Tingkat Atas (SLTA) Negeri dan Swasta di Kota Tanjungpinang, Provinsi Kepulauan Riau. Jurnal Ilmiah Manajemen Universitas Putera Batam, 7.

Suarya, G. N. P. (2018). Studi Evaluasi Profesionalisme Guru Prakarya dan Kewirausahaan Ditinjau Persepsi Siswa XI MIA SMAN 4 Singaraja. Jurnal Pendidikan Teknik Elektro Undiksha, 7(1), 20-30. http://dx.doi.org/10.23887/jjpte. v7i1.20217.

Tanjung, A. (2019). Pengaruh Persepsi Kepemimpinan Transformasional Kepala Sekolah, Budaya Sekolah dan Motivasi Berprestasi Terhadap Komitmen Afektif Guru SMP Negeri di Wilayah Tanjung Morawa Kabupaten Deli Serdang. Jurnal Penelitian Dan Pengabdian Masyarakat, $\quad$ 8(1). $\quad$ https://jurnal.uisu.ac.id/index.php/ wahana/article/view/1450.

Trisnowati, W. M. (2019). Pengaruh Motivasi, Kepemimpinan Transformasional, Disiplin Terhadap Komitmen dan Kinerja Guru. Jurnal Manjemen, 1(2), 2622-6367. https://ejournal.umaha.ac.id/index.php/iq tisad/article/view/544.

Wahidin, W. (2020). Pengaruh Kepemimpinan Transformasional Kepala Sekolah Dan Motivasi Kerja Terhadap Kinerja Guru SMK Negeri Jakarta Utara. Tadbir : Jurnal Studi Manajemen Pendidikan, 4(1), 151. https://doi.org/10.29240/jsmp.v4i1.1274.

Wardoyo, T. (2018). Kontribusi Kepemimpinan Transformasional, Iklim Organisasi Sekolah, dan Motivasi Berprestasi Terhadap Kinerja Guru. Media Manajemen Pendidikan, 1(2), 194. https://doi.org/10.30738/mmp.v1i2.3250.

Wasito, E. (2021). Pengaruh Komitmen Organisasional terhadap Kinerja Guru Dimoderasi oleh Kepemimpinan Transformasional Kepala Sekolah dan Lingkungan Kerja di SMK Kabupaten Pemalang. Jurnal Ilmiah Ilmu Pendidikan, 4. http://jiip.stkipyapisdompu.ac.id/jiip/ index.php/JIIP/article/view/205.

Zulkarnaen, Z. (2020). Pengaruh Budaya Sekolah, Gaya Kepemimpinan Transformasional, dan Motivasi Kerja Terhadap Kinerja Guru SMK. Jurnal Akuntabilitas Manajemen Pendidikan, 8(2), 175-185. https://doi.org/10.21831/ jamp.v8i2.33867. 